\title{
BIOTECHNOLOGY DEVELOPMENTS IN UGANDA AND ASSOCIATED CHALLENGES
}

\author{
J. ECURU and H. NALUYIMA \\ Uganda National Council for Science and Technology, P. O. Box 6884, Kampala, Uganda \\ Corresponding author: jbecurus@yahoo.com
}

\begin{abstract}
Biotechnology is an important tool whose application Ugandan scientists are exploring in crop, fish and livestock improvement, value addition, waste management, and in medicine. However, the continuing growth of biotechnology or more broadly, biosciences as an enterprise in Uganda will depend on the support given to science and technology generally. To accelerate this growth, Government must ensure supportive science and technology structures such as: a national science funding facility for research and technology development; institutional governance systems which promote innovativeness, and high quality education at all levels to maintain a constant supply of a skilled bioscience workforce. Specific measures at institutional level could include: establishing more synergies between biotechnology programmes and strengthening interactions among the actors both locally and internationally; integrating biotechnology into institutional programmes and regulatory instruments; putting in place technology management policies and developing capacities for their implementation; encouraging private sector participation in commercialization of bioscience innovations, supporting spin-off bioscience-based companies through a national innovation and commercialization fund; and eliminating administrative bottlenecks in procurement and financial management through early and more coordinated planning. This paper gives highlights of biotechnology developments and the associated challenges in Uganda.
\end{abstract}

Key Words: Bioscience, biotechnology, policies, science and technology

\section{RÉSUMÉ}

La biotechnologie est un important instrument dont l'application sert les scientistes ugandais à explorer l'amélioration des cultures, des poisons et du bétail, addition de la valeur, la gestion des dechets et la médicine. Par ailleurs, la croissance continue de la biotechnologie ou plus au sens large, bioscience comme une entreprise en Ouganda dependra du soutien généralement accordé à la science et technologie. Pour accélérer cette croissance, le Gouvernement doit garantir son soutien aux structures de la science et technologie tels que: un fonds national pour le développement de la recherche et technologie; des systèmes institutionnels de gouvernance pour promouvoir de l'innovation et une éducation de haute qualité à tous les niveaux pour maintenir une constante fourniture d'une compétante main d'oeuvre en bioscience. De mesures spécifiques au niveau institutionnel pourrait inclure: l'établissement une synergie entre les programmes de biotechnologie et renforcer les interactions parmi les acteurs locaux et internationaux; integration de la biotechnologie aux programmes institutionnels et instruments régulatoires; mise en place d'une politique de gestion des technologies et développement des capacities pour leur exécution; encouragement de la participation du secteur privé dans la commercialisation des innovations de la bioscience; appui des enterprises de production des services bioscientifiques à travers de fonds nationaux d'innovation et de commercialisation; et elimination des contraintes liées à la gestion de finances et l'approvisionnement par une coordination bien planifiée et faite à temps. Cet article présente les développements et les contraintes associés à la biotechnologie en Ouganda.

Mots Clés: Bioscience, biotechnologie, politique, science et technologie 


\section{INTRODUCTION}

Uganda has embraced science, technology and innovation as the cornerstone for economic growth and development (Ministry of Finance, Planning and Economic Development, 2010). Priority appears to be in promoting science education, research in and value addition to bio and agro-based products. The country could have a competitive edge in developing a bio-resource economy given its rich natural resource potential. For this reason, biotechnology is rapidly advancing within the country as a tool to improve crop, livestock and fish production, manage toxic wastes, and develop new materials and improve medical diagnostics and therapeutics. However, the continued growth of biotechnology as an enterprise will depend a lot on how the multiplicity of actors in the field relate with each other, and the foundational support given to science and technology generally . This paper presents key achievements and challenges in biotechnology in Uganda.

Historical perspective. Mila Avramovic (1996) described biotechnology as "a variety of techniques involving living organisms or their parts as a means of production”. Traditionally, baking bread, brewing beer and making cheese and yoghurt employ biotechnology. In this paper, however, biotechnology is closely associated with transgenic organisms or use of recombinant DNA techniques.

Biotechnology became prominent in Uganda around 1993 when the Department of Animal Science in the Faculty of Agriculture at Makerere University proposed to test a transgenically derived bovine somatotropin (BST) hormone for growth and milk production in Ugandan cattle. The BST hormone which was to be imported was produced through the genetic engineering of agrobacteria. At the time, the United States of America and the European Union (EU) were deeply engaged in debate over trade on genetically modified organisms. Later that year, in November 1993, the EU placed a moratorium on the sale of BST.

In 1995, another proposal was made to conduct a Phase 1 clinical trial of a candidate HIV-1 vaccine (ALVAC vCP 205). The vaccine construct was a live recombinant canary pox vector expressing HIV-1 glycoproteins 120 and 41. It was the first preventative HIV-1 vaccine study in Uganda and in Africa. The BST and ALVAC vCP 205 vaccine proposals made to Uganda National Council for Science and Technology (UNCST) to a large extent formed the basis for the formulation of national biosafety guidelines, leading to the establishment of a National Biosafety Committee in 1996 (Ssebuwufu, 1998). Later, in April 2008, government passed a national biotechnology and biosafety policy for Uganda.

To date, research into biotechnology continues and remains strategic for Uganda. This research ranges from laboratory-based investigations of novel genes conferring resistance to pathogens, drought and other biotic and abiotic stresses, to field trials of transgenic crops, for example, banana, cotton, maize, potato and cassava. Any prospects of moving promising transgenic products to the market require a proper understanding of the constraints and opportunities within the biotechnology innovation system as a whole.

Biotechnology research and development in Uganda. Biotechnology research and development related work in Uganda is growing (Baguma and Sengooba, 2007; Juma and Serageldin, 2007). The following are highlights of some of the work:

In agriculture, molecular markers are being used to characterize crop pathogens (e.g. the fungus cercospora zeae-maydis which causes gray leaf spot disease in maize and the sweetpotato feathery mottle virus). Genetic diversity of crops, and marker assisted selection for viral and disease resistance (e.g. resistance to cassava mosaic disease, cassava brown streak virus and coffee wild disease) are also being studied. Research is being done to genetically improve East African highland bananas for resistance to banana bacterial wilt, nematodes and weevils as well as to enhance its nutritional value. Confined field trials of bio-engineered bananas which begun in 2007 to confer resistance against black Sigatoka disease caused by the fungus Mycosphaerella fijiensis continue at the National Crop Resources Research 
Institute (NACRRI) near Kampala City. Further, confined field trials of herbicide tolerant and insect resistant transgenic Bacillus thuringiensis (Bt) cotton and transgenic cassava resistant to cassava brown streak virus begun at National Semi-Arid Resources Research Institute and NACRRI, respectively. Micropropagation of bananas and pineapples using tissue culture for commercial purposes is being done at Agro-Genetic Technologies Ltd (AGT). The latter is also exploring new protocols for coffee multiplication.

In the livestock subsector, identification of drug resistant trypanosome genes is ongoing. Other work include development of animal vaccines and improved diagnostic tools for Bovine pleuropneumonia, Newcastle disease, and east cost fever.

In the health sector, molecular markers are being used to study the pharmacokinetics and characterization of drug resistance, especially resistance to anti-malarial drugs, anti tuberculosis drugs (multi-drug and extremelydrug resistant tuberculosis), and antiretroviral drugs for HIV/AIDS. Phase 1 clinical trials of DNA based vaccines developed elsewhere using recombinant adeno 5 virus vector are also ongoing.

In the field of environment, genetic markers are being developed to characterize various species of wildlife including elephants, hippopotamus, buffalo and fish. The results of these studies would be used for conservation planning. A search for and bioengineering of microorganisms to optimize nitrogen removal from heavily contaminated sites is ongoing.

Over the years, organizations in Uganda have developed capabilities for bio-engineering work. Table 1 shows capabilities in 8 leading organizations in Uganda that carry out biotechnology related work.

Human capital in biotechnology. Systematic efforts to build a critical mass of biotechnology experts in Uganda started in the late 1990s. The East African Research Network for Biotechnology, Biosafety and Biotechnology Policy Development (BIO-EARN) Programme

TABLE 1. Key biotechnology capabilities in 8 institutions

\begin{tabular}{|c|c|c|c|c|c|c|c|c|}
\hline \multirow[t]{2}{*}{ Common Techniques } & \multicolumn{8}{|c|}{ Institution } \\
\hline & FoAMU & NARLI & NACCRI & MBL & AGT & JCRC & UVRI & FaVMU \\
\hline DNA finger printing & $X$ & $X$ & $x$ & $x$ & & $X$ & $x$ & $x$ \\
\hline Transformation & & $x$ & & & & & & $x$ \\
\hline Marker Assisted Selection & $x$ & & $x$ & & & & & \\
\hline Tissue culture-micro-propagation & $x$ & $x$ & $x$ & & $x$ & & & \\
\hline Tissue culture- disease elimination & $x$ & & & & & & & \\
\hline Tissue culture -germplasm conservation & & & & & & & & \\
\hline Tissue culture-somatic embryogenesis & $x$ & $x$ & & & & & & \\
\hline Diagnostics-PCR & $x$ & $x$ & $x$ & $x$ & & $x$ & $x$ & $x$ \\
\hline Diagnostics-ELISA & $x$ & $x$ & $x$ & $x$ & & $x$ & $x$ & $x$ \\
\hline Gene cloning & & $x$ & & & & $x$ & $x$ & $x$ \\
\hline Microarrays/Real time PCR & & & & & & $X$ & $x$ & \\
\hline Nucleic acid hybridization & & $x$ & & $x$ & & $x$ & $x$ & $x$ \\
\hline DNA Sequencing & & & & & & $x$ & $x$ & \\
\hline Proteomics & & & & & & $x$ & $x$ & $x$ \\
\hline
\end{tabular}

Key

FoAMU- Faculty of Agriculture, Makerere University

NARLI- National Agricultural Research Laboratories Institute

MBL- Med Biotech Laboratories

JCRC- Joint Clinical Research Centre

UVRI- Uganda Virus Research Institute

FaVMU- Faculty of Veterinary Medicine, Makerere University 
which started in 1998 was one of the pioneer programmes to provide targeted training in biotechnology. The programme initially trained four Ugandans at doctoral (Ph.D.) level in biotechnology related areas through a sandwich between Makerere University and Universities in Sweden. The programme continued to train twelve students at masters (M.Sc.) and two more students at Ph.D. level using the capacity it had developed.

Other initiatives such as the Rockefeller Foundation, USAID, and Association for Strengthening Agricultural Research in East and Central Africa (ASARECA) have also made significant contributions in training more human resources in biotechnology. Consequently, modest capacity now exists within the country to supervise biotechnology training at postgraduate levels, provided students can occasionally access more advanced facilities abroad, such as the state-of-the-art scientific facilities at Biosciences East and Central Africa in the International Livestock Research Institute in Nairobi, Kenya. Already, this arrangement for biotechnology training is being implemented by a number of programmes including Agricultural Biotechnology Support Programme of the USAID, BIO-EARN, BiosafeTrain, ASARECA, Regional Universities Forum (RUFORUM), and the Uganda Millennium Science Initiative of the UNCST. Together, these programmes will train locally up to 70 M.Sc. and 20 Ph.D. students in biotechnology related areas by 2012 . Biotechnology related work was by end of 2009 being undertaken by a total core scientific workforce of about 200 scientists only, 30\% of whom had Ph.D. and about the same number with M.Sc. Technicians and related support personnel comprised the remaining $40 \%$ of the workforce. To increase this human capacity, RUFORUM initiated in 2008/09 a new regional postgraduate programme which offers taught Ph.D. and M.Sc. in Plant Breeding and Biotechnology. The postgraduate programme is hosted by Makerere University (in the Faculty of Agriculture).

Biotechnology governance and regulatory issues. Government approved a National Biotechnology and Biosafety Policy for Uganda in April 2008. The policy aims to ensure safe application of biotechnology in Uganda. The policy paves way for use of genetic engineering and related techniques in all fields of science and technology. The specific aims of the policy are to build and strengthen Uganda's biotechnology research and development capacity, promote use of biotechnology in production, provide a sound regulatory framework for bioengineered organisms and promote the ethical and responsible use of biotechnology for national development purposes. There were no specific policies which appeared to hinder biotechnology in Uganda. However, plans are underway to enact a National Biosafety Bill, which is hoped would create a much stronger legal framework for biotechnology in Uganda.

UNCST is the national agency for coordination of biotechnology and biosafety in Uganda. It has over the years developed functional systems for biosafety management of research protocols on bioengineered organisms, and is coordinating the regulation of biotechnology in the country. These efforts resulted in the adoption of the aforementioned National Biotechnology and Biosafety Policy (2008) and the drafting of a Biosafety Bill. Nevertheless, given the cross cutting nature of biotechnology, other regulatory agencies such as the National Drug Authority, the Phytosanitary Inspection Division of the Ministry of Agriculture, Animal Industry and Fisheries, Uganda National Bureau of Standards, and National Environment Management Authority also need to integrate biotechnology and biosafety into their existing regulatory regimes and institutional programmes. These agencies are, by virtue of their mandates, partners in the regulation of bioengineered products and services in the country. It is important, therefore, that they revise and update their regulatory instruments to cover bioengineered products and services as well, and develop specific capabilities for their implementation in this regard.

Public research organizations and universities need institutional intellectual property or technology management policies to protect proprietary knowledge and information, and to allow easy licensing and/or transfer of 
technology. Such institutional policies facilitate regional and international collaboration and exchange of research materials and information; and the development of partnerships for product development, especially with the private sector. So far, only Makerere University, has an institutional intellectual property and innovation policy which was approved in early 2008. Other universities and research organizations including, for example, the National Agricultural Research Organization, the Uganda Industrial Research Institute, need to establish theirs too.

Administrative inefficiencies in financial and procurement management are emerging challenges public research organizations and universities must address. In 2003, Government enacted the Public Procurement and Disposal of Public Assets Act which prescribes rules and procedures of how public funds ought to be used to acquire goods, works and services. The law aims, inter alia, at ensuring the application of fair, competitive, transparent, nondiscriminatory and value for money procurement and disposal standards and practices by public agencies. This procurement law is not, however, well understood by most scientists, and many public organizations still struggle with its implementation. As a result, there have been inefficiencies in procurement, leading either to delays in acquiring goods, works and services or scientists not getting items with the right specifications for their work. In so far as most research is externally funded, and even when locally financed, proper accountability for funds and more efficient procurement management are paramount in sustaining research collaborations, and ensuring timely and high quality scientific work. Therefore, early procurement planning and timely procurement are necessary, and the scientists themselves as users must be involved in the procurement process.

Interactions among biotechnology actors. In Uganda, key actors in biotechnology research and innovation are in the public research organizations and universities, mainly Makerere University and the National Agricultural Research Institutes. The actors somehow know each other, but not so much about what each one is doing. Interactions among them are generally weak and very informal, as it depends on the initiative of an individual scientist. Interactions with the private sector are even much weaker, although it is common to find active scientists/ researchers in the public sector who make reasonable effort to collaborate with private organizations -firms, farmers and nonGovernmental organizations. Firms are often reluctant to reciprocate because they tend to focus more on immediate results and short term financial gains (salary and allowances). It is, therefore, difficult to trace a true symbiotic relationship between public sector scientists and entrepreneurs in the private sector.

However, collaborations between local scientists and their counterparts abroad appears to be stronger, perhaps because foreign partners have more advanced scientific facilities which the local scientists can access periodically. Partners abroad also provide training opportunities for local scientists to enhance their skills, and are also seen as a gateway to international research funding sources. In this regard, it is important that Ugandan scientists develop and nurture strategic international science and technology partnerships to support growth of the biotechnology enterprise in Uganda.

In all, interactions among local biotechnology actors in Uganda as well as with their counterparts abroad need to be strengthened. One way would be to have more "bio2biz" type of fora focusing on enterprise development opportunities arising from bioscience innovations in the public research organizations. The aim of such fora would be to seek collaboration with partners at the outset of research and to identify partners in product development and dissemination. These would be complimentary forums to ongoing initiatives such as the Open Forum for Agricultural Biotechnology (OFAB) which was established in December 2007 through partnership between UNCST, International Food Policy Research Institute's Program for Biosafety Systems, and the African Agricultural Technology Foundation headquartered in Nairobi, Kenya. The OFAB is a monthly luncheon organized by UNCST which brings together scientists, policy makers, media and the public to discuss topical agricultural 
biotechnology related issues globally and nationally.

Financing of biotechnology. A larger proportion of biotechnology work in Uganda is funded from abroad. Most of the financing comes through research collaborations, and draw from competitive grants in the international community. The major sponsors of biotechnology work by 2009 were: Swedish International Development Agency (Sida) through the BIO-EARN Programme and the bilateral research collaboration program between Makerere University and Swedish universities, USAID, Rockefeller Foundation, Bill and Melinda Gates Foundation through the Alliance for a Green Revolution in Africa (AGRA), ASARECA, Monsanto and Government of Uganda through the Uganda Millennium Science Initiative (MSI) project.

A sustainable national funding mechanism for research and technology development is required in Uganda. Government should establish a national science funding mechanism which is predictable, transparent and merit based, and which makes grants for research and technology development available annually both directly and on a competitive basis. This dual financing arrangement for research and innovation is not new. Countries with a true commitment to advancing science and technology as an engine for economic growth and development have established their own national science funding agencies. South Africa, for example, has the National Research Foundation and United States of America has the National Science Foundation. Countries like these compete favourably in the international market, because their industry and commerce is backed by science and technology strategically financed from domestic sources. In Uganda, an emerging good example would be the MSI which in 2007, 2008 and 2009 awarded several large grants on a competitive basis to support research, innovation, and science curriculum development. This type of funding allows for training of more scientists, equipping research facilities, and can sustain longer term research and innovation programs in organizations, including enlarging employment opportunities for scientists. Government can build on the success of its MSI, and allocate more resources to it so that grants are awarded annually to productive research groups. It is estimated that Government contribution of approximately US\$ 5 to 8 million annually to the MSI type of funding in the medium term would support implementation of more than 50 large research programmes with at least 250 scientists participating in any given year. In this way, scientists would be motivated to think creatively and innovatively all the time, because they would be assured, somehow, of a possibility of getting funding for their projects. It is also an incentive to retain highly skilled scientists in the country and to attract those in the Diaspora. Further, it is arguably the most appropriate way to support and sustain bilateral cooperation in science and technology and joint research activities. By adopting such dual financing for research and innovation, government tap the real potential of Ugandan scientists to contribute to economic growth and national prosperity.

Additionally, some type of "bridging finance" would be needed. That is, small amounts of money which would facilitate the crucial product development phase of an innovation, moving the innovation sufficiently along the product development pathway for it to become of interest to potential private partners. Such funding would be provided through a microcredit scheme or as alluded to above through an innovation fund such as the existing Presidential Support to Scientists fund, and the Uganda MSI grants for technology platforms.

Private sector involvement. Private bioscience-based enterprises in Uganda are yet to evolve. Public research organizations will for some long time be the major players in biotechnology research, product development and dissemination. However, Government can encourage private commercialization of bioscience innovations by supporting spin-off bioscience-based companies. Spinoffs would have an added advantage of attracting more technically skilled workforce into private sector. However, for a start, Government could provide venture capital for innovation and 
commercialization of research products independently or through the Uganda Development Corporation, to interested scientists who would like to start a biosciencebased enterprise. Government has to intervene because there are no private venture capitalists in the country as yet for bioscience-based innovations.

Furthermore, private sector could be deliberately supported to exploit business opportunities that arise from innovations in public research organizations. Public research organizations should not only focus on directly commercializing their innovations; but they may also, through well established technology management policies, license these innovations to the private sector.

\section{CONCLUSION}

The biotechnology or more broadly, biosciences enterprise in Uganda is growing, but this growth is dependent on the foundational support given to science and technology generally within the country. Strong supportive science and technology structures are needed. These include: a national science funding facility for research and technology development; institutional governance systems which promote innovativeness; and high quality education at all levels to maintain a constant supply of a skilled scientific workforce. In addition, public research organizations in Uganda need play a more active role in forging the links which are essential for innovation.

\section{REFERENCES}

Avramovic, M. 1996. An Affordable Development? Biotechnology, Economics and the Implications for the Third World, ZED Books, London and New Jersey.

Cao, H., Kaleebu, P., Flores, J., El-Habib, R., Salata, R., Mbidde, E., Mugyeni, P., Ellner, J. and Mugerwa, R. 2002. HIV-specific Cytotoxic T Lymphocyte (CTL) response in seronegative Ugandan volunteers vaccinated with HIV-ALVAC vCP 205: result of the phase I HIVNET 007 vaccine study. International Conference on AIDS. 2002. Jul 7-12; 14: abstract no. TuOrA1226. CA Dept Health Services, Richmond, United States.

Clark, N., Mugabe, J. and Smith, J. 2007. Biotechnology Policy in Africa. ACTS Press, Nairobi, Kenya.

Juma, C. and Serageldin, I.. 2007. Freedom to Innovate: Biotechnology in Africa's Development- A Report of the High Level African Panel on Modern Biotechnology. African Union and New Partnership for Africa's Development. Addis Ababa (Ethiopia) and Pretoria (South Africa).

Ministry of Finance, Planning and Economic Development. 2010., National Development Plan 2010/11 - 2014/15. Government of Uganda, Kampala, Uganda.

Ssebuwufu, P.J.M. 1998. Opening Speech: Proceedings of the first workshop to review matters related to biotechnology and biosafety, 14-15 October 1998 in Kampala, Uganda. 